\title{
Preliminary results of renewal pruning an 18 years old sour cherry trees
}

\author{
Vaszily, B. \\ Research and Extension Centre for Fruit Growing Vadastag 2, H-4244 Ujfeherto, Hungary
}

\begin{abstract}
Summary: Sour cherry is a light demanding fruit species. As most of the crop is developing from buds on one year old shoots and 2-yearold wood, the formation of bare wood can be seen apparently in a badly maintained canopy. The formation of ,whip shoots" indicates the degree of bare wood. Unfortunately in many gardens and commercial orchards sour cherry trees resemble willow trees. Owners often decide to grub old orchards, although the useful cropping lifespan of the trees planted in a correct spacing can be 20-30 years on a move vigorous rootstock. Therefore renewal pruning can contribute to the full renewal of the orchard, but the length of its effect is depending on the growth characteristics and renewal capabilities of the cultivar. The growth characteristics of the cultivars are different. The regeneration capabilities of different aged wood are also different. These differences emphasize the need for cultivar specific pruning. Knowing the reactions to renewal pruning, we can ensure regular high crops with excellent quality by applying cultivar specific rotation pruning.
\end{abstract}

Key words: regeneration ability, sour cherry cultivars, renewal pruning

\section{Introduction}

Sour cherry is a Hungaricum. Even so in Hungary have some old, neglected and outdated orchards. According to some growers sour cherry trees don't need to pruning. This faith causes probably the use of the large trees (Gonda, 2008, 2010).

As a most of the crop is developing from buds on one years old shoots, so it is mean, that it must prune all years. The purpose of pruning was stimulated to form shoots.

Of course without pruning formed shoots too. If shoots formed from summit bud without pruning, this causes the formation of "whip shoots'. It is reduced yield and fruit quality to long-term aging of the trees.

The variety-specific technology gives excellent fruit quality (Vaszily, 2012). The growing habits of the cropped sour cherry varieties have a few differences than other fruit. Sour cherry trees make faster loss of branches; ability of regeneration is milder than sweet cherry cultivars. (Gonda, 2010).

Aims is to determining that the regeneration ability to 18 year old cherry tree with full renewal response and is referred to as "new" crown design development faster.

\section{Materials and methods}

Experiments have been performed in at Debrecen-Pallag, on the Experimental Farm of Horticulture and Regional Research Centre.

The sour cherry trees were planted in spring of year 1995, on Prunus mahaleb rootstock. For the study two varieties were selected as considered most important. 'Újfehértói fürtös' was at $5 \mathrm{~m} \times 3 \mathrm{~m}$ planting design, 'Debreceni bőtermö' was $5 \mathrm{~m} \times 4 \mathrm{~m}$ planting. The trees trained to a slender spindle crown forms.

The renewal pruning was doing all over the tree in spring of year 2013. We cut back all branches. The length of remaining branches (stump) was different long.

The sprouting of growth from hidden buds was measured in October. Summing up the one year old shoots, the ability of regeneration has been determined. The second order branches were determined too. The renewal ability of the sour cherry varieties has been characterized by the number of one year old shoot existing on branches of length and diameter.

\section{Results}

On Table 1 shows the renewal shoots of the different length of stump (per current meter). The number of shoots of 'Debreceni bötermö' were $81 \mathrm{pc} / \mathrm{m}$. It is $7 \%$ more than 'Újfehértói fürtös'. All lengths of shoots show the same. The length of shoots of 'Debreceni bötermö' have longer regeneration points. Effect of renewal pruning 'Debreceni bőtermö' was formed longer shoots. It is $27 \%$ more than 'Újfehértói fürtös'.

On Table 1 shows the number of shoots per diameter on the remaining branches. However, on this basis 'Újfehértói fürtös' has more shoots. The length of shoots per diameter on the branches shows, that 'Debreceni bőtermö' formed longer regeneration shoots the effect of the renewal pruning.

The average length of 'Debreceni bötermö' is more (52 $\mathrm{cm})$ than 'Újfehértói fürtös' $(43 \mathrm{~cm})$ (Table 2). However, the growths rate of various size categories are very different. 
All cultivars formed most of the shoots between 40-100 $\mathrm{cm}$ and 11-25 $\mathrm{cm}$. Lowest proportion of shoots were short shoots (between 1-10 cm) and long shoots (above $100 \mathrm{~cm}$ ).

'Debreceni bőtermő' was formed more shoots above 40 $\mathrm{cm}$. 'Újfehértói förtös' was formed more shoots between 11-40 cm.

On Table 3 shows the regeneration growths of second order branches. 'Debreceni bőtermő' showed better results in the summarized regeneration growths. However, the growths of second order branches of 'Újfehértói fürtös' formed a lot more than 'Debreceni bötermő'. This secondary shoots were longer and have more pieces. This property is very affordable, allowing to shape the crown more quickly (VASZILY, 2012). The average length of second order shoots was similar.

Table 1. Regeneration characteristic of 18 years old sour cherry trees after renewal pruning (Debrecen-Pallag, 2013)

\begin{tabular}{|l|c|c|}
\hline \multicolumn{1}{|c|}{ Sour cherry cultivars } & $\begin{array}{c}\text { 'Újfehértói } \\
\text { fürtös' }\end{array}$ & $\begin{array}{c}\text { 'Debreceni } \\
\text { bötermö' }\end{array}$ \\
\hline $\begin{array}{l}\text { Length of regeneration shoots (m)/stump } \\
\text { curretnt meter (m) }\end{array}$ & 31,43 & 42,73 \\
\hline $\begin{array}{l}\text { Pieces of regeneration shoots (pc)/ stump } \\
\text { curretn meter (m) }\end{array}$ & 76,09 & 81,13 \\
\hline All shoot lengths (cm)/ stump diametr (cm2) & 44,43 & 46,35 \\
\hline All shoot pieces (pc)/ stump diameter (cm2) & 1,04 & 0,89 \\
\hline
\end{tabular}

Table 2. Rate of regeneration growths in different size categories (\% (Debrecen-Pallag, 2013)

\begin{tabular}{|l|c|c|}
\hline & 'Újfehértói fürtös' & 'Debreceni bötermö' \\
\hline $1-10 \mathrm{~cm}$ & 7,9 & 4,9 \\
\hline $11-25 \mathrm{~cm}$ & 29,2 & 20,8 \\
\hline $26-40 \mathrm{~cm}$ & 19,1 & 18,8 \\
\hline $40-100 \mathrm{~cm}$ & 38,2 & 47,5 \\
\hline $100 \mathrm{~cm}<$ & 5,6 & 7,9 \\
\hline Shoot length $(\mathrm{cm})$ & 43,1 & 52,0 \\
\hline
\end{tabular}

Table 3. The regeneration growths of second order branches (Debrecen-Pallag, 2013)

\begin{tabular}{|l|c|c|c|}
\hline $\begin{array}{c}\text { Sour cherry } \\
\text { cultivars }\end{array}$ & $\begin{array}{c}\text { Length of } \\
\text { second order } \\
\text { branches }(\mathrm{cm})\end{array}$ & $\begin{array}{c}\text { Length of } \\
\text { second order } \\
\text { branches per } \\
\text { current meter } \\
\text { of first order } \\
\text { branch }(\mathrm{cm} / \mathrm{m})\end{array}$ & $\begin{array}{c}\text { Piece of second } \\
\text { order branches } \\
\text { per current } \\
\text { meter of first } \\
\text { order branch } \\
(\mathrm{pc} / \mathrm{m})\end{array}$ \\
\hline $\begin{array}{l}\text { 'Újfehértói } \\
\text { fürtös' }\end{array}$ & 40,3 & 591,6 & 14,7 \\
\hline $\begin{array}{l}\text { 'Debreceni } \\
\text { bőtermö' }\end{array}$ & 34,2 & 228,8 & 6,7 \\
\hline
\end{tabular}

\section{Conclusions}

The summarized regeneration growths of 'Debreceni bőtermő' were longer and have more pieces than 'Újfehértói fürtös'. The number and length of second order shoots were fewer 'Újfehértói fürtös'. Therefore, this variety is considered favorable length of regenerative growths. This shoots must cut back (that is branchered), to accelerate make up for crown.

The summarized regeneration growths of 'Újfehértói fürtös' were shorter and fewer pieces but his second order branches were better.

My results show, that the species, which have a more pieces and longer (over $40 \mathrm{~cm}$ ) -due to the inhibitory effect of auxin $\neg$ less tendency to form a second-order branches. So those varieties formed more pieces of secondary branches, which formed shoots a major proportion below $40 \mathrm{~cm}$.

The results show, the abilities of regeneration showed different. The effect of renewal pruning is different too. It is evident that a variety-specific technology is needed for economical.

The degree of bare wood is characteristic features. This extent can be influenced or delayed by the regular pruning. If the renewal pruning done expertly can renewed the old trees.

\section{Acknowledgements}

„This research was realized in the frames of TÁMOP 4.2.4. A/2-11-1-2012-0001 ,National Excellence Program Elaborating and operating an inland student and researcher personal support system" The project was subsidized by the European Union and co-financed by the European Social Fund."

\section{References}

Gonda, I. (2008): Anbau-und Erziehungssysteme, Kroneformen und Baumschnitt. [In Nyéki et al. (2008): Sauerkirschenanbau.] Debreceni Egyetem AMTC, KFI. 32-35. p.

Gonda, I. (2010): Csonthéjas gyümölcsfák metszése. DE AMTC KFI, Gonda István Betéti Társaság, Debrecen

Vaszily, B. (2010/a): A study of processes active in regeneration of different sweet cherry varieties. International Journal of Horticultural Science, 16 (1): 55-57.

Vaszily, B. (2010/b): A metszés időpontjának és a cseresznyefajták termőrészképződésének összefüggései. Agrártudományi Közlemények, 41: 131-134.

Vaszily, B. (2012): Cseresznyefajták regenerációs tulajdonságai az eltérő korú koronarészektől függően. Kertgazdaság 44. (1): 28-34. 